\title{
DESAIN BAHAN AJAR SAINS TERPADU MENGINTEGRASIKAN NILAI KARAKTER CERDAS BERBASIS ICT UNTUK PEMBELAJARAN SISWA SMP KELAS VIII
}

\author{
Asrizal $^{(1)}$, Ramadhan Sumarmin ${ }^{(2)}$, Iswendi ${ }^{(3)}$, dan Trisya Gustiya ${ }^{(4)}$ \\ (1) Jurusan Fisika,FMIPA Universitas Negeri Padang, Padang(asrizal_unp@yahoo.com), \\ (2) Jurusan Biologi, FMIPA, Universitas Negeri Padang \\ (3) Jurusan Kimia, FMIPA, Universitas Negeri Padang \\ ${ }^{(4)}$ Mahasiswa Program Studi Pendidikan Fisika, FMIPA, Universitas Negeri Padang
}

\begin{abstract}
ABSTRAK
Integrasi merupakan suatu ide yang menarik dalam kurikulum 2013. Untuk SMP, integrasi antara bidang IPA, integrasi nilai karakter, dan integrasi ICT proses pembelajaran sangat penting dilakukan. Pembelajaran Sains di SMP seharusnya dilakukan secara terpadu karena pada dasarnya alam merupakan satu kesatuan. Fakta menunjukkan bahwa Sains di SMP masih terpisah-pisah. Tujuan dari penelitian adalah untuk menjelaskan cara integrasi nilai karakter ke dalam bahan ajar berbasis ICT dan menggambarkan hasil desain dari bahan ajar Sains terpadu berbasis ICT. Penelian yang dilakukan dapat dikelompokkan ke dalam penelitian dan pengembangan yaitu suatu penelitian yang menghasilkan produk tertentu dan menguji efektivitas dari produk tersebut. Ada empat langkah penelitian yang telah diterapkan yaitu: mengenal potensi dan masalah, mengumpulkan informasi, dan mendesain produk bahan ajar. Berdasarkan desain pengembangan produk bahan ajar Sains terpadu berbasis ICT dapat dikemukan dua hasil dari penelitian ini. Pertama, cara yang digunakan untuk mengintegrasikan nilai-nilai karakter cerdas ke dalam bahan ajar adalah melalui informasi , instruksi, dan analogi. Menu utama bahan ajar Sains terpadu berbasis ICT mengintegrasikan nilai karakter terdiri dari home, identitas, kompetensi, pendahuluan, materi pembelajaran, latihan soal, uji kompetensi, referensi dan menu pendukung.
\end{abstract}

\section{KATA KUNCI: Integrasi, Sains, Sains Terpadu, Nilai Karakter, ICT}

\section{PENDAHULUAN}

Pendidikan sains memiliki peranan yang penting dalam menyiapkan peserta didik untuk memasuki dunia kehidupannya. Sesuai dengan karakteristiknya, pendidikan sains memiliki potensi dan peranan strategis dalam menyiapkan SDM yang berkualitas untuk menghadapi era globalisasi. Potensi ini akan dapat diwujudkan jika pendidikan sains mampu menghasilkan peserta didik yang terampil dalam proses sains, memiliki sikap ilmiah, dan menerapkannya dalam kehidupan. Beberapa keterampilan sains seperti berpikir logis, berpikir kreatif, kemampuan memecahkan masalah, bersifat kritis, menguasai teknologi, dan kemampuan beradaptasi sangat penting dalam kehidupan.

Penerapan pembelajaran yang berkualitas merupakan suatu faktor penentu keberhasilan pendidikan sains. Sesuai dengan standar proses seharusnya pembelajaran sains dapat dilakukan secara interaktif, inspiratif, menyenangkan, menantang, memotivasi siswa untuk berpartisipasi secara aktif, dan memberikan ruang yang cukup untuk mengembangkan prakarsa, kreativitas, dan kemandirian siswa. Dengan cara ini peserta didik dapat mengkonstruksi pengetahuan tentang gejala alam melalui proses sains. Dengan proses sains yang baik, peserta didik dapat mengembangkan sikap ilmiah seperti ingin tahu, kritis, jujur, terbuka, objektif, tekun, dan sebagainya.

Sesuai dengan karakteristik Sains, pada hakikatnya pembelajaran Sains dilakukan secara terpadu. Sains terpadu merupakan Sains yang disajikan sebagai satu kesatuan yang tidak terpisahkan, artinya siswa tidak belajar ilmu Fisika, Biologi, dan Kimia secara terpisah sebagai mata pelajaran yang berdiri sendiri, melainkan semua diramu dalam kesatuan (Das S: 2009). Sebagai contoh air adalah bagian dari alam yang tidak bisa hanya dilihat dari segi fisika, kimia, atau biologi, tetapi merupakan kesatuan air dengan segala kandungan dan sifat-sifatntya.

Pembelajaran terpadu merupakan pendekatan pembelajaran yang secara sengaja mengaitkan beberapa aspek baik dalam intra mata pelajaran maupun antar mata pelajaran (Ranta MS: 2012). Dengan keterpaduan siswa memperoleh pengetahuan dan keterampilan secara utuh sehingga pembelajaran menjadi bermakna. Bermakna berarti siswa dapat memahami konsep-konsep yang dipelajari melalui pengalaman langsung yang menghubungkan antar konsep dalam intra mata pelajaran maupun antar mata pelajaran.

Dari segi ilmu psikologi dan pendidikan, seorang siswa akan lebih mudah mengenal dan memahami benda-benda di alam secara keseluruhan 
terlebih dahulu dan bukan melalui bagian-bagiannya yang terkecil. Pembelajaran sains terpadu sangat sesuai diterapkan untuk siswa SMP dibandingkan jika diberikan secara terpisah. Pembelajaran sains terpadu dipercaya lebih mampu menumbuhkan kreativitas siswa dan lebih menyenangkan sehingga sesuai dengan tuntutan standar proses.

Model pembelajaran sains terpadu direkomen dasikan ditingkat SMP, karena ternyata memiliki beberapa tujuan yaitu: meningkatkan efesiensi dan efektivitas pembelajaran, meningkatkan minat dan motivasi, dan beberapa kompetensi dasar dapat dicapai sekaligus. Keunggulan pembelajaran sains terpadu: efisien dan efektif, materi-materi tidak saling tumpang tindih antara satu dengan yang lain. Selain itu, waktu pembelajaran dapat dihemat untuk kegiatan lapangan, meningkatkan minat dan motivasi, mempermudah dan memotivasi siswa untuk memahami konsep pengetahuan secara menyeluruh. Beberapa kompetensi dasar dapat dicapai sekaligus, model pembelajaran sains terpadu dapat menghemat waktu, tenaga dan sarana, serta biaya pendidikan (Ari G: 2011).

Salah satu altenatif untuk membantu penerapan pembelajaran Sains terpadu adalah bahan ajar. Bahan ajar berbasis ICT adalah bahan ajar yang disusun dan dikembangkan dengan menggunakan alat bantu ICT untuk mengolah data, termasuk memproses, mendapatkan, menyusun, menyimpan, memanipulasi data dalam berbagai cara untuk menghasilkan informasi yang berkualitas. Dalam kegiatan pembelajaran, penggunaan bahan ajar ICT memungkinkan peserta didik dapat mempelajari suatu kompetensi dasar (KD) secara runtut, sistematis, interaktif dan inovatif sehingga diharapkan semua kompetensi tercapai secara utuh dan terpadu (Ibnu F: 2010).

Bahan ajar berbasis ICT merupakan bahan yang dengan sengaja disiapkan untuk keperluan belajar sebagai alat untuk membantu siswa menguasai teknologi informasi dan materi pelajaran dengan lebih cepat, menyenangkan dan meningkatkan hasil belajar. Pengembangan bahan ajar berbasis ICT menjadi kebutuhan yang mendesak untuk tercapainya kualitas pembelajaran yang diharapkan (Cheppy R: 2008).

Melalui bahan ajar integrasi nilai karakter dapat dilakukan. Karakter merupakan watak, tabiat, akhlak, atau kepribadian seseorang yang terbentuk dari hasil internalisasi berbagai kebajikan yang diyakini dan digunakan (Edi P: 2011). Nilai-nilai karakter merupakan sikap dan perilaku yang didasarkan pada norma yang berlaku di masyarakat yang mencakup aspek spritual, personal, sosial, dan lingkungan (Lidya FH : 2012).

Integrasi nilai pendidikan karakter dapat dilakukan kedalam pembelajaran untuk membentuk karakter siswa. Pengintegrasian nilai-nilai karakter bangsa kedalam kegiatan pembelajaran berarti memadukan, memasukkan, dan menerapkan nilai-nilai yang diyakini baik dan benar dalam rangka membentuk, mengembangkan, dan membina tabiat atau kepribadian peserta didik sesuai jatidiri bangsa tatkala kegiatan pembelajaran berlangsung. Integrasi nilai-nilai karakter bangsa pada kegiatan pembelajaran dapat dilakukan melalui tahap-tahap: perencanaan, pelaksanaan, dan evaluasi (Anik G: 2009).

Untuk lebih memfokuskan pembahasan ini perlu dilakukan pembatasan masalah. Pertama, Sains terpadu untuk siswa SMP meliputi tiga bidang ilmu yaitu Biologi, Fisika, dan Kimia. Kedua, nilai karakter yang diintegrasikan ke dalam bahan ajar ada delapan yaitu: religious, rasa ingin tahu, gemar membaca, jujur, kerja keras, bersahabat/ komunikatif, disiplin, dan tanggung jawab.

Tujuan dari penulisan artikel ini adalah untuk menjelaskan cara mengintegrasikan nilai karakter cerdas ke dalam bahan ajar dan menggambarkan hasil desain produk bahan ajar Sains terpadu dengan mengintegrasikan nilai karakter cerdas.

\section{METODE}

Jenis penelitian yang telah dilakukan adalah Penelitian dan Pengembangan (R7D). R\&D adalah metode penelitian yang digunakan untuk menghasilkan produk tertentu, dan menguji keefektifan produk tersebut (Sugiyono: 2006). Disisi lain R\&D adalah suatu proses atau langkah-langkah untuk mengembang kan suatu produk baru atau menyempurnakan produk yang telah ada, yang dapat dipertanggung jawabkan (Nana S.S: 2006). Berarti produk merupakan bagian yang penting pada penelitian ini.

Objek dari penelitian adalah bahan ajar Sains terpadu berbasis ICT dengan mengintegrasikan nilai karakter. Objek dirancang berdasarkan struktur bahan ajar berbasis ICT. Pengembangan bahan ajar menggunakan sistem manajemen pembelajaran menggunakan software joomla. Kemudian bahan ajar divalidasi oleh tenaga ahli.

Secara ada tiga langkah dari sepuluh langkah penelitian dan pengembangan yang dikemukan oleh Sugiyono (2006). Pertama, mengenal potensi dan masalah. Kedua, mengumpulkan informasi tentang pemanfaatan ICT dalam pembelajaran di sekolah. Ketiga, mendesain bahan ajar Sains terpadu dengan mengintegrasikan nilai karakter.

\section{HASIL DAN PEMBAHASAN}

Pengintegrasian suatu bidang ilmu dengan bidang ilmu lain lain sains, nilai karakter, dan keterampilan ICT penting dalam dalam pembelajaran. Secara umum ada dua hasil pembahasan dalam tulisan ini. Pertama, cara integrasi antara bidang dalam Sains, integrasi nilai karakter, dan integrasi keterampilan ICT. Kedua, desain utama dari produk perangkat pembelajar an berbasis ICT dengan mengintegrasikan nilai karakter. 
1. Integrasi Nilai Karakter ke Dalam Bahan Ajar

Pembentukan dan pengembangan nilai karakter dalam pembelajaran perlu dilakukan secara berkelan jutan dalam proses pembelajaran. Menurut kurikulum 2013 pembelajaran yang dilaksanakan pada kegiatan inti dilakukan untuk membentuk kompetensi siswa. Kompetensi meliputi pengetahuan, sikap, dan keterampilan. Dalam prakteknya, pemben tukan pengetahuan dan keterampilan dilakukan terlebih dahulu. Efek penyerta dari pembentukan pengetahuan dan keterampilan adalah terbentuknya karakter siswa selama kegiatan inti.

Pengintegrasian nilai pendidikan karakter dapat pula dilakukan melalui perangkat pembelajaran. Dalam kuriku lum 2013, nilai-nilai karakter pada suatu mata pelajaran telah diintegrasikan pada kompetensi spiritual dan kompetensi sosial pada kompetensi inti. Dari kedua kompetensi inti ini, nilai karakter diturunkan ke kompetensi dasar. Karena itu, dalam kurikulum 2013 nilai karakter lebih mudah diintegrasikan ke dalam silabus dan RPP.

Integrasi nilai karakter dalam bahan ajar dapat dilakukan melalui beberapa cara. Pertama, melalui instruksi pada beberapa bagian bahan ajar seperti panduan dan latihan. Kedua, melalui informasi dalam materi pembelajaran. Ketiga, melalui analogi dari suatu konsep atau prinsip dari Sains dalam bahan ajar.

Strategi integrasi nilai karakter melalui instruksi dalam bahan ajar lebih mudah dilakukan. Dengan memberikan perintah, nasehat, larangan pada bagian tertentu nilai karakter dapat ditumbuhlan. Sebagai contoh instruksi dalam latihan yang dapat diberikan antara lain: bacalah doa sebelum mengerjakan latihan agar hati menjadi tenteram, kerjakanlah latihan dengan sunguh-sunguh agar didapat hasil yang lebih optimal, bekerjalah dalam kelompok dengan saling bersahabat, menghargai, dan komunikatif. Kerjakan lah latihan dalam bahan ajar dalam waktu 30 menit dengan bertanggung jawab.

Strategi integrasi nilai karakter kedua dalam bahan ajar yang dapat dilakukan adalah melalui materi pembelajaranr. Informasi nilai karakter dapat dihubungkan dengan nilai religius, rasa ingin tahu, dan gemar membaca. Sebagai contoh materi energi dapat dihubungkan dengan kebesaran dan kekuasaan kebesaran Tuhan dalam menciptakan matahari sebagai sumber energi utama dalam kehidupan dimuka bumi. Siswa diharapkan memikirkan, memanfaatkan, dan menyukuri tentang hasil ciptaan Tuhan ini.

Strategi integrasi nilai karakter dalam bahan ajar yang ketiga adalah melalui analogi dengan mengambil makna yang tersirat dalam suatu konsep, prinsip, atau hukum dalam Sains. Pada hakikatnya Sain merupakan suatu ilmu pengetahuan yang mempelajari tentang hasil ciptaan Tuhan. Dari segi Sains, secara umum hasil ciptaan Tuhan ada dua bagian yaitu peristiwa dan benda-benda di alam semesta.
Banyak makna dan pelajaran yang dapat diambil dari mempelajari peristiwa alam dan benda-benda. Sebagai contoh matahari setiap hari memancarkan energinya ke permukaan bumi dalam bentuk radiasi. Energi matahari digunakan oleh tumbuh-tumbuhan untuk proses fotosintesis. Disisi lain zat-zat makanan di sekitar akar tanaman dibawa oleh air ke daun. Pada daun terjadi perubahan energi cahaya kedalam energi kimia. Makna yang dapat diambil adalah saling adanya interaksi dan kerjasama dalam proses fotosistensis pada tanaman.

\section{Hasil Desain Bahan Ajar Berbasis ICT}

Desain bahan ajar Sains terpadu berbasis ICT dengan mengintegrasikan nilai karakter dikembangkan dengan sistem pengelolaan pembelajaran menggunakan software moodle. Tampilan halaman utama dari bahan ajar diperlihatkan pada Gambar 1

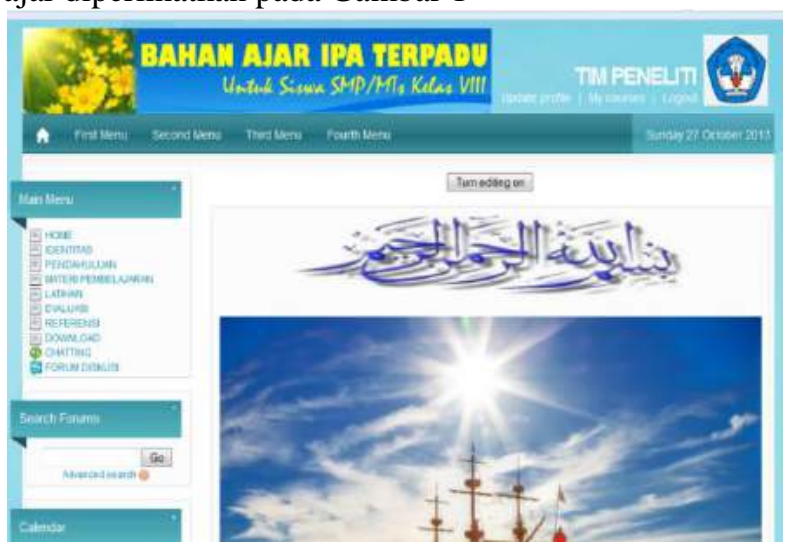

Gambar 1. Halaman Utama Bahan Ajar

Pada gambar 1, menu utama dari bahan ajar Sains terpadu terdiri dari home, identitas, pendahuluan, materi pembelajaran, latihan pemecahan soal, dan referensi. Disamping itu pada bahan ajar juga ditambahkan beberapa menu pendukung yaitu download, chatting, dan forum diskusi. Pembaca dapat masuk ke setiap bagian dari menu utama.

Pada menu pendahuluan terdapat tiga pilihan sebagai pengantar bagi pengguna sebelum mengguna kan bahan ajar. Tampilan menu pendahuluan dapat diperhatikan pada Gambar 2.

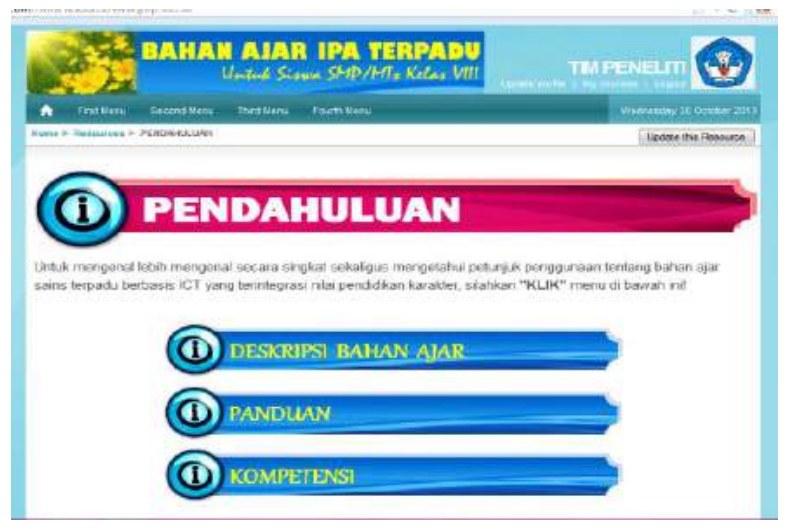




\section{Gambar 2. Pendahuluan Bahan Ajar}

Dari Gambar 2 dapat dikemukakan bahwa deskripsi menggambarkan tentang bahan ajar. Panduan berisi langkah-langkah yang perlu dilakukan oleh pengguna dalam menggunakan bahan ajar. Disisi lain kompetensi berisi kompetensi dasar dan indikator pencapaian yang dijadikan sebagai acuan dalam pengembangan tujuan dan materi pembelajaran.

Menu materi berhubungan dengan materi pembelajaran Sains terpadu. Tampilan menu materi dalam bahan ajar dapat diperhatikan pada Gambar 3.

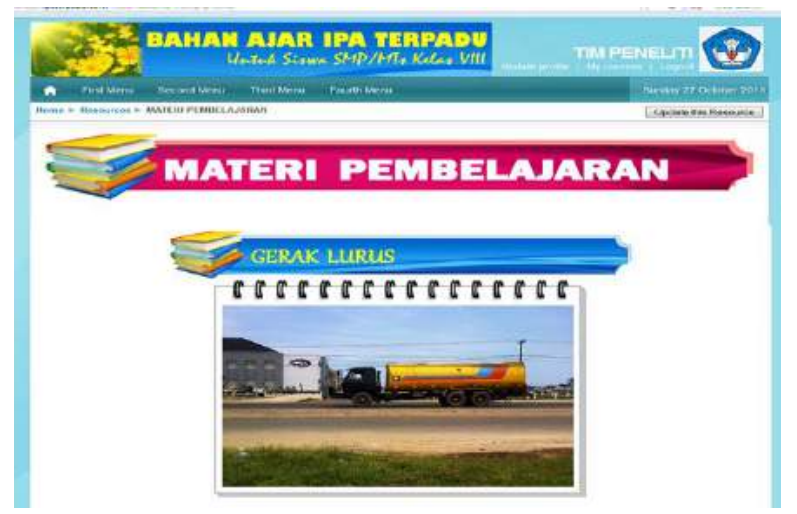

Gambar 3. Materi Pembelajaran dari Bahan Ajar

Pada gambar 3 dapat dijelaskankan bahwa materi pembelajaran dalam bahan ajar ada enam yaitu: gerak lurus, usaha dan energi, pesawat sederhana, gaya dan pengaruhnya, hukum Newton, dan tekanan. Setiap materi pembelajaran terdiri dari judul, tujuan, dan materi pembelajaran.

Pada menu latihan terdapat beberapa latihan pemecahan soal. Untuk satu latihan terdiri dari dua bagian yaitu soal pilihan ganda dan soal esai. Tampilan dari menu latihan diperlihatkan pada Gambar 4

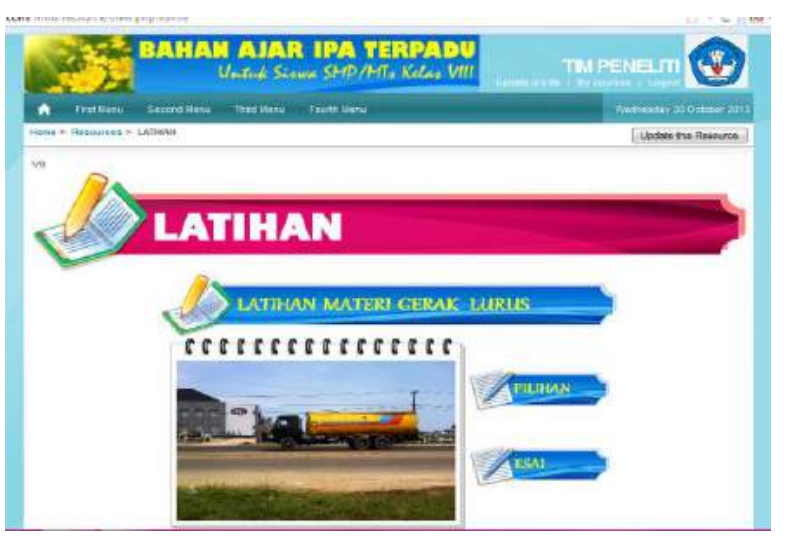

Gambar 4. Latihan Pemecahan Soal

Setiap latihan pemecahan soal berhubungan dengan materi pembelajaran yang sesuai. Sebagai contoh latihan materi gerak lurus berhubungan dengan materi dari gerak lurus tersebut. Pada latihan dalam bentuk pilihan terdapat soal-soal interaktif. Siswa berlatih menyelesaikan soal dan melakukan refleksi terhadap hasil kerjanya. Pada soal essai siswa dapat memasukkan jawaban secara langsung ke dalam kotak yang tersedia dan menyimpannya.

Penguasaan siswa untuk suatu kompetensi dasar perlu di cek melalui uji kompetensi. Tampilan evaluasi untuk suatu kompetensi dasar dapat diperhatikan pada Gambar 5.

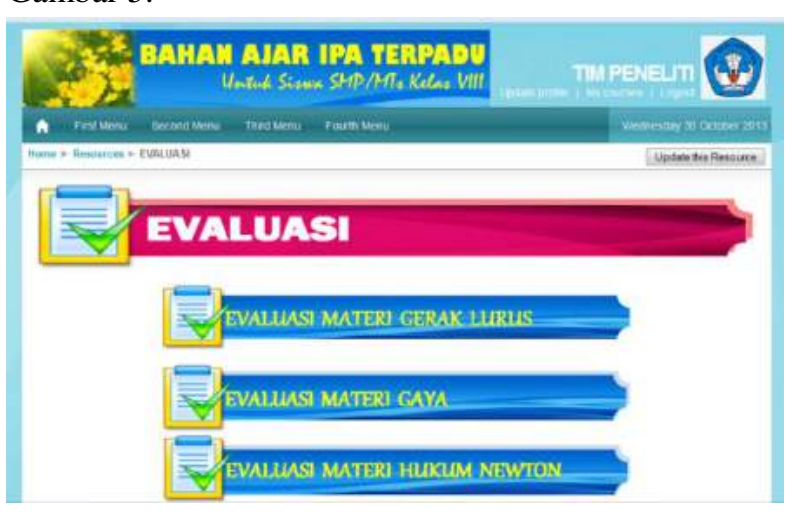

Gambar 5. Evaluasi Setiap Kompetensi

Menu evaluasi ini digunakan apabila siswa telah selesai mempelajari satu kompetensi dasar. Kegiatan evaluasi dilakukan secara online. Siswa diharapkan mengerjakan dengan jujur dari setiap soal yang diberikan pada evaluasi. Setelah kegiatan evaluasi siswa dapat mengetahui hasil yang diperolehnya.

\section{KESIMPULAN}

Berdasarkan desain pengembangan produk bahan ajar Sains terpadu berbasis ICT dapat dikemukan dua hasil dari penelitian ini.

1. Cara yang digunakan untuk mengintegrasikan nilainilai karakter cerdas ke dalam bahan ajar adalah melalui informasi, instruksi, dan analogi.

2. Menu utama bahan ajar Sains terpadu berbasis ICT mengintegrasikan nilai karakter terdiri dari home, identitas, kompetensi, pendahuluan, materi pembelajaran, latihan soal, uji kompetensi, referensi dan menu pendukung.

\section{UCAPAN TERIMA KASIH}

Kegiatan penelitian dan penulisan artikel ini dapat terlaksana karena bantuan dari berbagai pihak yang terkait. Dengan dasar ini peneliti mengucapkan terima kasih kepada:

1. Bapak Direktur Penelitian dan Pengabdian Masyarakat Direktorat Jenderal Jenderal Pendidikan Tinggi Kementerian Pendidikan dan Kebudayaan yang telah menggalokasi dana BOPTN kepada Universitas negeri Padang.

2. Rektor Universitas Negeri Padang yang telah mengalokasikan dana untuk pelaksanaan penelitian program desentralisasi skema hibah bersaing Tahun 2013. 
3. Ketua lembaga penelitian Universitas Negeri Padang yang telah mengelola pelaksanaan program desentralisasi skema hibah bersaing tahun 2013.

4. Dekan FMIPA Universitas Negeri Padang yang telah menginformasikan dan memfasilitasi tentang adanya program desentralisasi skema hibah bersaing tahun 2013 .

\section{DAFTAR PUSTAKA}

Anik Gufron, (2009). Integrasi Nilai-Nilai Karakter Bangsa Pada Kegiatan Pembelajaran. Universitas Negeri Yogyakarta.

Ari Gunawan, 2011. Pendidikan IPA Terpadu, Harus Bisa!. Kompasiana

Ceppy Riyana, 2008. Peranan Teknologi Dalam Pem belajaran. http://chepy. files.wordpress./com/ 2006/ 08/peran-teknologi.pdf

Das Salirawati, 2009. Pembelajaran Terpadu Untuk Mendukung Kreativitas Siswa. Jurusan Pendidik an Kimia FMIPA UNY

Edi Prayitno, 2011. Pendidikan Nilai-Nilai Budaya dan Karakter Bangsa Dalam Pembelajaran Matematika di SMP. Kementrian Pendidikan Nasional

Ibnu Fajar, 2010. Panduan Penyusunan Bahan Ajar Berbasis TIK. Informasi Pendidikan, Berbagai informasi berbagai dunia pendidikan, profesi keguruan, kemajuan ilmu pengetahuan dan teknologi. http://ibnufajar75. blogspot. com/2010/ 06/paduan-penyusunan-bahan-ajar-berbasis.html

Lydia Freyani Hawadi, 2012. Pedoman Pendidikan Pada Pendidikan Anak Usia Dini. Kementrian Pendidikan Nasional

Nana, S.S, 2000. Metode Penelitian Pendidikan. Program Pascasarjana Universitas Pendidikan Indonesia dan PT Remaja Rosdakarya.

Ratna Mega Sari, 2012. Pengembangan Bahan Ajar Membaca dan Menulis Naskah Drama Terintegrasi Siswa SMP/MTs Kelas VIII. Universitas Negeri Malang, Jalan Semarang 5 Malang

Sugiyono, 2006. Metode Penelitian Pendidikan: Pendekatan Kuantitatif, Kualitatif, dan $R \& D$. Alfabeta, Bandung. 